\title{
Евгения Дмитриева
}

$$
\underset{\substack{\text { Member since } \\ \text { JM14477 }}}{2019}
$$

https://orcid.org/0000-0001-5117-5677

Волгоградский государственный университет

Институт филологии и межкультурной коммуникации

Кафедра русской филологии и журналистики

400062, г. Волгоград, пр-т Университетский, 100

eg_dmitrieva@volsu.ru

\section{Функции эмотивной лексики как средства реализации религиозно-нравственного идеала в житийных текстах XVIII-XX веков}

\section{Functions of emotive vocabulary as a means of pursuing religious and moral ideal in the hagiographic texts of the 18th-20th centuries}

\section{Резюме}

В статье представлены результаты анализа оригинальных агиографических текстов XVIII-XX веков, которые изучены с позиций синхронно-диахронического подхода как единый массив, характеризующийся общностью культурных смыслов, передаваемых языковыми единицами, и свидетельствующий о непрерывности русской житийной традиции, которая во многом обеспечивалась опорой на выявленные значимые для русской языковой картины мира личностные качества подвижника, составляющие религиозно-нравственный идеал.

При анализе эмотивной лексики, используемой в агиографических текстах, было установлено, что лексика эмоций в житии выявляет существенные для понимания концепции автора смыслы, становится важным средством создания образа святого. Данные языковые единицы употребляются в ключевых фрагментах житийного текста с целью описания и характеристики людей, предметов и явлений действительности, связаны с использованием топосов и реализуют в житии ряд функций, прежде всего - характерологическую и текстообразующую. При реализации характерологической функции релевантны следующие параметры: 1) статус характеризуемого субъекта (святой / обычный человек); 2) характер обозначаемой глаголом эмоции (положительная / отрицательная / нейтральная) и ее интенсивность (низкая / средняя / высокая); 3 ) причина эмоционального переживания. Выступая связующим элементом содержательно-смыслового пространства и формальной организации текста в анализируемых житиях, лексика эмоций реализует текстообразующую функцию.

Ключевые слова: житие, эмотивная лексика, лексическая семантика, функционирование. 


\section{Summary}

The article shares the results of an analysis of original hagiographic texts from the period between the 18th and 20th centuries from the standpoint of the synchronous-and-diachronic approach as a single array characterized by common cultural meanings conveyed by linguistic units. It demonstrates the continuity of the Russian hagiographic tradition, which was largely relying on personal qualities that were significant for the Russian linguistic consciousness of hallowed individuals and based on the religious and moral ideal.

The analysis of emotive lexis helped highlight the methods of composing the images of saints in hagiographic texts. It is also intended to convey the author's major concepts. Such lexical items have several functions. They are found in the central segments of texts that characterize people, objects, and various phenomena. Besides, they provide descriptions of the topos. The following parameters are distinguished: 1) the status of the described object (saint/ordinary person); 2) the specificity of an emotion conveyed in the verb (positive/negative/neutral) as well as its intensity (low/medium/high); 3 ) the cause of emotional suffering. In hagiographic texts the lexis of emotions seems to be a link between the content and the formal structure of the text, thus fulfilling a text-composing function.

Keywords: hagiography, emotive vocabulary, lexical semantics, functioning.

\section{ВВОДНЫЕ ЗАМЕЧАНИЯ}

Интерес к вопросам семантики и функционирования языковых единиц в лингвистических исследованиях вызван необходимостью дальнейшего изучения соотношения языка и текста, большой перспективностью применения современных методов семантического и лингвокультурологического анализа к объектам языковой системы в разные периоды ее развития.

В центре нашего внимания находится фундаментальная проблема отражения в языке культурно значимых смыслов, рассматриваемая применительно к конкретному текстовому материалу в аспекте концептуализации представлений о нравственном идеале в русском религиозном языковом сознании.

Материалом для исследования послужили языковые факты, извлеченные методом сплошной выборки из малоизученных житийных текстов XVIII-XX вв. Для сопоставления привлекались данные житий начала XXI в. Языковой материал принимается за единый массив фактов.

Нравственный идеал рассматривается нами как широкая категория, характерная для разных типов человеческих обществ; применительно к русским агиографическим текстам следует говорить о религиозно-нравственном идеале как морально-этической норме, образце человеческого поведения и отношений между людьми, черпающем свои истоки в христианских ценностях и добродетелях, тесно связанном с представлениями о святости, но не тождественном ей.

В выражении нравственно-религиозного идеала в житийном тексте особую роль играет лексика эмоций, что обусловлено ее особой функциональной нагрузкой. 


\section{ФУНКЦИИ ЭМОТИВНОЙ ЛЕКСИКИ В ЖИТИЙНОМ ТЕКСТЕ: ОБЩАЯ ХАРАКТЕРИСТИКА}

По словам Н.С. Трубецкого, автор жития решает ряд задач, описывая события жизни подвижника, которые должны сделать его примером для подражания и свидетельствовать о его избранности (Трубецкой, 1995). Применительно к эмотивам в этой связи можно говорить о реализации ими в агиографическом тексте целого комплекса функций.

Во-первых, обращает на себя внимание тот факт, что в своем поведении герои житий часто руководствуются эмоциями. Таким образом, эмотивы, указывая на причинно-следственные связи, называя мотивы поступков, косвенно играют роль в развитии сюжета (сюжетоформирующая функция).

Во-вторых, лексика эмоций, выступая в качестве ключевых слов, формирует смысловые доминанты текста, определяет его композицию (текстообразующая функция).

В-третьих, посредством описания эмоциональных переживаний героев, автор текста дает им прямую или косвенную характеристику (характерологическая функция).

B-четвертых, описание эмоциональной жизни подвижника, а также его высказывания по этому поводу выступают как поучение для читателя (дидактическая функция).

В-пятых, эмотивы являются важнейшим средством концептуализации и экспликации представлений о внутреннем мире человека, ценностных ориентирах (лингвокультурная функция).

В-шестых, эмотивы формируют особый эмоциональный фон повествования, выражающий православное мирочувствование (мировоззренческая функция).

Думается, что среди названных функций собственно лингвистическое содержание имеют характерологическая, текстообразующая и лингвокультурная.

\section{ХАРАКТЕРОЛОГИЧЕСКАЯ ФУНКЦИЯ ЭМОТИВНОЙ ЛЕКСИКИ}

1. Под характерологической функцией языковых единиц в нашей работе понимается «употребление их в речи (тексте) с целью описания и характеристики людей, предметов и явлений действительности» (Дмитриева, 20116, 44).

К факторам, определяющим специфику реализации характерологической функции, относятся: 1) статус характеризуемого субъекта (святой/ 
обычный человек); 2) характер обозначаемой эмоции (положительная/ отрицательная/ нейтральная) и ее интенсивность (низкая/ средняя/ высокая); 3) причина эмоционального переживания (Дмитриева, 2011). Рассмотрим данные факторы подробнее.

Носителями эмоционального переживания в агиографическом тексте выступают святые или подвижники, а также священники и миряне. В каждом случае перечень «допустимых» эмоций будет разным. Так, святые или подвижники не могут характеризоваться лексемами, обозначающими отрицательные чувства, направленные на другого человека, такими как ненавидеть, ненависть, гнев, гневаться, ярость и под. Следует отметить, что переживания, которыми наделяется Бог, стоят несколько особняком. Н.А. Бердяев писал по этому поводу:

Богу... нисколько не боятся приписать гнев, ревность, месть и пр. аффективные состояния, которые считаются предосудительными для человека. Существует глубокая пропасть между пониманием человеческого совершенства и Божественного совершенства (Бердяев, 1998, 41).

Поскольку объектом рассмотрения в данном исследовании являются лексические средства репрезентации нравственного идеала, в фокусе нашего внимания всегда находится святой или подвижник благочестия - центральный образ жития (жизнеописания).

Важным в тексте жития оказывается отражение языковыми единицами деления эмоциональных переживаний на положительные и отрицательные; не охарактеризованные по данному признаку в изолированном употреблении эмотивы мы относим к называющим нейтральные состояния (например, изумиться, изумление, дивиться, удивляться, удивление и под.).

Такое деление принято большинством лингвистов (см., например: Апресян, 1995; Шаховский, 2009; Banach, 1988; Borek, 2012; Duszak, Pawlak, 2003; Duszak, Pawlak, 2005; Wierzbicka, 1996 и др.) и опирается на принятые в психологии классификации (Вилюнас, 1984, 20). Однако если в психологии оно однозначно связано с противопоставлением полярных эмоций удовольствия / неудовольствия (см., например, в работах В. Вундта, Б.И. Додонова, К. Изарда, П.В. Симонова и др.), в языке и тексте это противопоставление осложняется связью личностных представлений с системой оценок, порождаемых обществом (ср. радость и злорадство). Поэтому так важно, на наш взгляд, говорить о причине эмоционального переживания.

Кроме того, описываемые в житиях эмоциональные переживания часто получают дополнительную характеристику по интенсивности.

2. Характерологическая функция эмотивной лексики в агиографическом тексте может проявляться двояко: с одной стороны, читатель получает представление о тех или иных чертах персонажа и оценивает его, исходя 
из демонстрируемых им чувств и эмоций, с другой стороны - сами эмоции могут получать ту или иную оценку, будучи соотнесенными с определенными субъектами. В первом случае речь идет об обычных людях - священнослужителях или мирянах, во втором случае эмоциональные переживания образуют жесткую систему координат, связываясь либо с божественными проявлениями, либо с дьявольскими.

Принятое в науке деление эмоций на положительные и отрицательные в житийных текстах теряет свою однозначность, поскольку положительные эмоции могут оцениваться отрицательно, а отрицательные - положительно. Например, выступая в нейтральном контексте, глагол бояться является глаголом состояния, обозначающим протекание отрицательной, средней по интенсивности эмоции, относящейся к сфере субъекта, характеризующегося как конкретный, одушевленный. Однако, когда речь идет о нуминозных эмоциях - о Страхе Божьем, он перестает обозначать отрицательную эмоцию:

страх, в разных модусах, постоянно присутствует в читательском восприятии жития. Но житийный страх не рабский, а подданнический, не болезнен, а сладостен, ведет к смирению и душевному миру и в этом смысле - очищает (Берман, 1982, 179-180).

Это вовсе не означает, что при характеристике подвижников автор жития не использует наименований отрицательных эмоций. Можно выделить допустимые (поощряемые) отрицательные эмоциональные переживания или их проявления. К таковым, в частности, относятся эмоции, называемые лексемами скорбь, скорбеть, плакать, плач и под. Существительное скорбь в житийных текстах выступает в двух значениях: «горесть, печаль, сокрушение духа» или «беда, несчастие» (Словарь церковно-славянскаго и русскаго языка.., 1847б, 136), глагол скорбеть отмечается в значении «чувствовать скорбь, печалиться» (Словарь церковно-славянскаго и русскаго языка.., 1847б, 136). В житийных текстах скорбь описывается как реакция на тяготы повседневной жизни, внешним проявлением этой скорби выступает плач, например:

Такъ пребываль отрокъ, упражняясь въ чтеніи и сказанномъ поученіи. Въ особенности же онъ скорбъль и плакаль, недоумЊвая - что дълать (Житіе молдавскаго стариа Паисія Величковскаго..., 1906, 9).

Обращаясь к монаху Амфилохию, ректор сказал, что существует три вида скорбей: это скорби, присущие всем христианам в их стремлении к небесному совершенству вследствие несоответствия действительности идеалу: «многими скорбми подобает нам внити в Царствие Божие» (Деян. 14, 22), эти скорби спасительны; во-вторых, это скорби уныния перед высотой Евангельского идеала. «Монахам присущ, второй вид скорбей, и путь избавления от них - это молитва и созерцание примеров добродетелей». И, в-третьих, 
это скорби пастырские, которыми страдал Христос в саду Гефсиманском в ночь, в которую был предан за спасение мира (Мф. 26, 38) (Игумен Дамаскин (Орловский), 2002, 6).

Отдельной составляющей религиозно-нравственного идеала можно считать борьбу с отрицательными эмоциями, называемыми в христианской традиции страстями:

Старец учил, что новоначальному иноку прежде всего должно заботиться о познании себя и укрощении своих страстей (Житие преподобного Льва, стариза Оптинского, 2017, 47);

«Не угашайте духа, но паче возгревайте его терпеливо молитвою и прилежным чтением святоотеческих и Священных Писаний, очищая сердие от страстей», - завещал умирающий Батюшка (Житие преподобного Варсонофия, 2017, 361).

Именно чистота сердца видится реализацией нравственного идеала:

Преподобный никогда ничем не соблазнялся, никого не осуждал и не порицал; ни о ком не изменял благой мысли; на все и на всех смотрел чистым оком, чем доказывал, что стяжал чистое сердие (Житие преподобного Антония, 2017, 147),

погруженность в жизнь духовную:

Старец Павел больше любил жить жизнью внутреннею, духовною, а потому мало заботился о внешней чистоте и опрятности (Житие святого Павла, стариа и чудотвориа Таганрогского, 2001, 30).

Важной составляющей характеристики святого является реакция на действия окружающих, испытывающих отрицательные чувства:

Отъ всего сердца и отъ всей души прощать ближнему всякое оскорбленіе, въ надеждъ отпущенія и своихъ грьховъ; ибо кто не прощаетъ ближнему своему проступковъ или какой-либо обиды, тотъ и самъ отнюдь не получить отпущенія грьховъ своихъ отъ отца небеснаго (Житіе молдавскаго стариа Паисія Величковскаго..., 1906, 9).

Идеалом в такой ситуации видится всепрощение и отпущение грехов.

Тем не менее отмечаются единичные случаи, когда подвижники испытывают сильные отрицательные чувства, направленные на объект:

Все обиды и печали блаженная сносила безропотно, лишь однажды, когда Ксения уже стала почитаться за угодницу Божию, жители Петербургской стороны видели ее в страшном гневе... Видя безропотность и беззащитность блаженной, они [злые дети] стали бросать в нее грязью и камнями. Тогда, по-видимому, и у блаженной не хватило терпенья (Святая блаженная Ксения Петербургская, 2014, 12-13). 
Однако во всех подобных случаях противоречие снимается причиной эмоционального переживания.

3. Таким образом, важным для понимания авторской интенции оказывается рассмотрение эмоциональных переживаний включенных в причинно-следственные отношения, то есть эмоции оцениваются еще и по тому, что их вызвало и к чему они привели. Например, так агиограф разъясняет, чего надо бояться:

отнюдь не осуждать ближняго своего, хотя бы и своими очами увидълъ, что онъ грђшить; ибо осуждающій ближняго своего самъ себъ присвояетъ достоинство Божіе; а есть ли что страшнъе сего? (Житіе молдавскаго стариа Паисія Величковскаго..., 1906, 8-9), -

а так на примере подвижника показывает, что нужно делать в минуты отчаяния:

Такъ пребывалъ отрокъ, упражняясь въ чтеніи и сказанномъ поученіи. Въ особенности же онъ скорбълъ и плакалъ, недоумъвая - что дълать. И вотъ онъ съ сокрушеннымъ сердцемъ и со многими и горькими слезами, бія въ перси свои, началь припадать ко Христу Богу и молиться дабы Онъ поставилъ его на путь спасенія (Житіе молдавскаго стариа Паисія Величковскаго..., 1906, 9).

Достаточно часто действия или качества подвижника выступают причиной эмоционального состояния окружающих и таким образом получают оценку:

Когда же Петръ, ставъ предъ святителемъ, толково и съ подобающею почтительностью произнесъ приготовленные къ сему случаю однимъ ученымъ мужемъ стихи, Владыка обрадовался, благословилъ его, и сказалъ: быть тебъ насльдникомъ (родительскаго мъста) (Житіе молдавскаго стариа Паисія Величковскаго..., 1906, 6).

Именно учет причинно-следственных связей внутри контекста (текста) позволяет полнее описать религиозно-нравственный идеал, поскольку оказывается важным не столько испытывать определенные чувства, сколько направлять их на определенные объекты:

И такъ любиль онъ молчаніе, что даже самая мать его ръдко слышала его говорящимъ; ибо онъ быль кротокъ, весьма стыдливъ и сдержанъ не только въ отношеніи къ людямъ постороннимъ, но и къ своимъ (Житіе молдавскаго стария Паисія Величковскаго..., 1906, 6).

\section{ТЕКСТООБРАЗУЮЩАЯ ФУНКЦИЯ ЭМОТИВНОЙ ЛЕКСИКИ}

Помимо характерологической, эмотивная лексика в агиографических текстах реализует еще ряд функций, к важнейшим из которых можно отнести текстообразующую, понимаемую нами как «способность языковых еди- 
ниц быть связующим элементом содержательно-смыслового пространства и формальной организации текста» (Дмитриева, Акимова, 2011, 46).

В Житии святителя Илариона, митрополита Суздальского, наиболее употребительными эмотивами являются лексемы с корнем -люб-: прилагательное любимый - «пользующийся большею перед другими любовью; предпочитаемый другому» (Словарь иеековно-славянскаго и русскаго языка.., 1847а, 274), существительные любимець - «пользующийся чьим-либо особенным благорасположением» (Словарь иерковно-славянскаго и русскаго языка.., $1847 \mathrm{a}, 274)$, любитель - «имеющий к чему-либо особенную привязанность» (Словарь церковно-славянскаго и русскаго языка.., 1847a, 274), любовь - «сердечная к кому-либо привязанность» (Словарь цуерковно-славянскаго и русскаго языка.., 1847a, 274), глагол полюбить - сов. к любить - «иметь к кому-либо любовь, сердечную привязанность», «иметь к чему-либо особую склонность» (Словарь церковно-славянскаго и русскаго языка.., 1847a, 274).

Как показал проведенный анализ, перечисленные языковые единицы употребляются в ключевых фрагментах житийного текста, связаны с реализацией топосов. Так, повествуя о детских годах святителя Илариона (в крещении - Иоанна), автор жития отмечает, что пребывание в монастыре помогло очень рано сделать выбор жизненного пути будущему подвижнику:

Такимъ образомъ едва не съ младенчества Богу угодно было поставить Іоанна свидътелемъ суровыхъ иноческихъ подвиговъ - и здъсь, въ безмолвіи монастыря, въ постъ, молитвъ, послушаніи, хожденіи въ церковь, протекло дътство будущаго подвижника Иларіона, и монашескіе подвиги сдълались навсегда любимымъ занятіемъ отрока Іоанна (Георгіевскій, 1914, 4).

Еще въ с. Кириковђ онъ былъ наученъ отцемъ своимъ грамотђ и здъсь въ монастырђ съ любовію предавался чтенію св. писанія и душеполезныхъ книгъ (Георгіевскій, 1914, 4).

Из чего можно заключить, что лексика эмоций в Житии является важным средством создания образа святого и выявляет существенные для понимания концепции автора смыслы, реализуя текстообразующую функцию.

Описывая жизнь подвижников, автор подчеркивает любовь, с которой они относились к окружающим и которая повсюду их сопровождала. Высокая частотность употребления лексем с семантикой любви, традиционно характеризующее тексты житий, можно считать проявлением житийного канона, нацеленного на установление определенной эмоционально-нравственной атмосферы, особого «православного» мирочувствования (мировоззренческая функция).

Тем не менее жизнь подвижника не всегда наполнена любовью окружающих:

Мачиха сильно не взлюбила свою падчерицу и всячески старалась выразить ей свое нерасположеніе (Блаженная Ирина Зеленогорская, 1996, 229); 
Благочестивая старица Ирина, перенеся немало горя отъ неразумныхъ на своемъ въку, тихо скончалась за молитвою, будучи почти ста льтъ отъ роду (Блаженная Ирина Зеленогорская, 1996, 230).

Однако неизменным остается терпение подвижника, его душевная стойкость, оптимизм:

Безпрерывно находясь въ трудъ, она глубочайшимъ смиреніемъ и своимъ неизмънно веселымъ настроеніемъ, съ какимъ исполняла всъ возлагавшіяся на нее работы, воодушевляла къ трудамъ и прочихъ сестеръ обители... (Блаженная Ирина Зеленогорская, 1996, 230).

Сопоставление разных текстов показало, что на фоне общей частотности лексем с корнем -люб- могут быть выделены повторяющиеся «ключевые характеристики» святых и подвижников в рамках отдельных житий. Например, чувство удивления, которое испытывают окружающие при общении с подвижником, является своеобразным маркером избранности:

Таково было усердіе къ Богу въ этомъ дивномъ еще десятильтнемъ отрокъ! Всђ видЂвшіе и слышавшіе о немъ люди благоразумные удивлялись его добронравію, ревности и усердию, и прославляли Бога... (Житіе молдавскаго стариа Паисія Величковскаго..., 1906, 6).

В качестве «ключевого» чувства может выступать и уважение:

Всъ жители Сънной площади ... относились къ ней съ глубокимъ уваженіемъ, видя въ ней не простую побирушку-нищую, а Христа ради юродивую... (Рахманинъ, 1908а, 3);

Еще большимъ уваженіемъ стала пользоваться А.И., когда стали замъчать, что она обладаеть замъчательнымъ даромъ прозорливости и что предсказанія ея исполняются буквально (Рахманинъ, 1908а, 3);

Молва о строгой, подвижнической жизни Анны Ивановны ... широко разнеслась по Петербургу и доставила Аннъ Ивановнъ ото всъхъ глубокое почитаніе и уваженіе, хотя сама Анна Ивановна всячески и старалась убъгать почитанія, для чего нерьдко заводила на улицахъ шумъ, ссоры то съ извозчиками, то съ прохожими (Рахманинъ, 1908a, 4).

\section{В жизнеописании блаженной Ксении ведущим чувством оказывается пере- живание счастья:}

Прожила она съ мужемъ около двухъ льтъ; дътей не имъла; по земному была вполнъ счастлива. Но неожиданная смерть молодого, любимаго мужа, въ которомъ для Ксеніи заключалась вся цђль и счастіе жизни, все измънила. Ксенія сразу поняла суетность счастія земного и рђшилась всецьло посвятить себя на достиженіе счастія на небђ, въ Богъ (Рахманинъ, 1908б, 3 с. 3-4);

Это мнъніе еще болъе усилилось, когда стали замъчать, что появленіе Ксеніи въ какомъ-либо домъ, или лавкъ, всегда приносило счастіе... (Рахманинъ, 1908б, 3 с. 3-4);

На могилку эту шли всъ удрученные какимъ-либо горемъ, всъ несчастные, и всъ они, по мърђ въры, получали молитвенную помощь и утьшеніе (Рахманинъ, 1908б, 3 с. 5). 
При этом важным оказывается развитие этого чувства: от счастья личного через счастье соприкосновения с Божественным к счастью общественному, служение которому может обеспечить добрую память и после смерти. Здесь воплощается важная, на наш взгляд, составляющая русского нравственного идеала - примат общественного, соборного над личным, индивидуальным, что позволяет говорить о реализации эмотивной лексикой еще одной функции - лингвокультурной.

\section{ВЫводы}

Таким образом, выявлены константные особенности употребления эмотивов, отмеченные в рассматриваемых житиях синодального и современного периодов и свойственные русской житийной традиции в целом: 1) значимость качественной характеристики эмоционального переживания (положительное/ отрицательное/ нейтральное), 2) наличие частотных («ключевых») лексем, определяющих общий эмоциональный фон житийного текста и позволяющих говорить как о типизации, так и об индивидуализации образа святого, 3) релевантность высокой интенсивности эмоционального переживания, свидетельствующей об ориентации на предельные нравственные значения, 4) реализация эмотивами комплекса собственно лингвистических (характерологической, текстообразующей, лингвокультурной) и экстралингвистических (сюжетоформирующей, дидактической и мировоззренческой) функций. Лексика эмоций в агиографических текстах выражает такие черты русского религиозно-нравственного идеала, как чистота сердца (полный отказ от страстей), любовь к ближнему и окружающему миру в целом, любовь «равная» и жертвенная, принятие скорбей земного бытия, терпение и недопустимость уныния.

\section{БИБЛИОГРАФИЯ}

Апресян, Ю.Д. (1995). Образ человека по данным языка: попытка системного описания. В: Избранные труды. Т. ІІ. Интегральное описание языка и системная лексикография, 348-388. Москва: Школа «Языки русской культуры», Издательская фирма «Восточная литература» РАН.

Бердяев, Н.А. (1998). О назначении человека. Москва: ТЕРРА - Книжный клуб; Республика. Берман, Б.И. (1982). Читатель жития (Агиографический канон русского средневековья и традииия его восприятия). В: Художественный язык средневековья, 159-183, В.А. Карпушин (ред). Москва: Наука.

Блаженная Ирина Зеленогорская (1996). В: Жизнеописания отечественных подвижников благочестия 18 и 19 веков.: Сентябрь, 226-230. Козельск: Введен. Оптина Пустынь. 
Вилюнас, В.К. (1998). Основные проблемы психологической теории эмоций. В: Психология эмоций. Тексты, 3-28. Москва: Издательство Московского университета.

Георгіевскій, В.Т. (1914). Житіе и подвиги святителя Иларіона, митрополита Суздальскаго. Петроградъ: Сvнодальная Типографія.

Дмитриева, Е.Г. (2011). Характерологическая функиия эмотивной глагольной лексики в древнерусских и старорусских текстах. В: Слово в языке и тексте, 42-55. Волгоград: Волгоградское научное издательство.

Дмитриева, Е.Г., Акимова, Э.Н. (2011). Функичии эмотивной лексики в Повести о Петре и Февронии. Вестник Волгоградского государственного университета, Серия 2, Языкознание. № 2(14), 45-49.

Игумен Дамаскин (Орловский) (2002). Житие священномученика Амфилохия (Сквориова), епископа Красноярского. Тверь: «Булат».

Житіе молдавскаго стариа Паисія Величковскаго (переложено со славянскаго на русскій языкъ архим. А.) (1906). Свято-Троицкая Сергіева Лавра: Собственная типографія.

Житие преподобного Антония (2017). В: Преподобные стариы Оптинские. Жития и наставления, 135-156. Введенский ставропигиальный мужской монастырь. Оптина пустынь.

Житие преподобного Варсонофия (2017). В: Преподобные стариь Оптинские. Жития и наставления, 345-363. Введенский ставропигиальный мужской монастырь. Оптина пустынь.

Житие преподобного Льва, стариа Оптинского (2017). В: Преподобные стариьы Оптинские. Жития и наставления, 35-50. Введенский ставропигиальный мужской монастырь. Оптина пустынь.

Житие святого Павла, стариа и чудотвориа Таганрогского (2001). Москва: Лествица.

Рахманинъ, Е. (1908а). Прот. Раба Божія Анна (Юродивая Анна Ивановна Лашкина или Лукашева). Санкт-Петербургъ: «Электропечатня» Я. Кровицкого.

Рахманинъ, Е. (1908б). Прот. Раба Божія Блаженная Ксенія. Санкт-Петербургъ: «Электропечатня» Я. Кровицкого.

Святая блаженная Ксения Петербургская (2014). Москва: Благовест.

Словарь иерковно-славянскаго и русскаго языка, составленный Вторымъ отдъленіемъ Императорской Академіи наукъ: в 4 m. (1847a). Т. 2. Санкт-Петербургъ: Въ Типографіи Императорской Академіи наукъ.

Словарь ичерковно-славянскаго и русскаго языка, составленный Вторымъ отдъленіемъ Императорской Академіи наукъ: в 4 m. (1847б). Т. 4. Санкт-Петербургъ: Въ Типографіи Императорской Академіи наукъ.

Трубецкой, Н.С. (1995). История. Культура. Язык. Москва: Издательская группа «Прогресс».

Шаховский, В.И. (2009). Язык и эмочии в аспекте лингвокультурологии. Волгоград: Перемена.

$* * *$

Banach, A. (1988). O szczęściu. Kraków: Wydawnictwo lit.

Borek, M. (2012). Uczucia i emocje $w$ rosyjskich i polskich metaforach. Aspekt lingwistyczny. Katowice: Uniwersytet Śląski; Oficyna Wydawnicza.

Duszak, A., Pawlak, N. (red.) (2003). Anatomia gniewu. Emocje negatywne w językach i kulturach świata. Warszawa: Wydawnictwo Uniwersytetu Warszawskiego.

Duszak, A., Pawlak, N. (red.) (2005). Anatomia szczęścia. Emocje pozytywne w językach i kulturach świata. Warszawa: Wydawnictwo Uniwersytetu Warszawskiego.

Wierzbicka, A. (1996). Semantics. Primes and universals. New York-Oxford: Oxford University Press. 
Apresyan, Yu.D. (1995). Obraz cheloveka po dannym yazyka: popytka sistemnogo opisaniya. V: Izbrannye trudy. T. II. Integral'noe opisanie yazyka i sistemnaya leksikografiya, 348-388. Moscow: Shkola «Yazyki russkoi kul'tury», Izdatel'skaya firma «Vostochnaya literatura» RAN.

Berdyaev, N.A. (1998). O naznachenii cheloveka. Moscow: TERRA - Knizhnyi klub; Respublika. Berman, B.I. (1982). Chitatel'zhitiya (Agiograficheskii kanon russkogo srednevekov'ya i traditsiya ego vospriyatiya). V: Khudozhestvennyi yazyk srednevekov'ya, 159-183, V.A. Karpushin (red). Moscow: Nauka.

Blazhennaya Irina Zelenogorskaya (1996). V: Zhizneopisaniya otechestvennykh podvizhnikov blagochestiya 18 i 19 vekov.: Sentyabr', 226-230. Kozel'sk: Vveden. Optina Pustyn'.

Dmitrieva, E.G. (2011). Kharakterologicheskaya funktsiya emotivnoi glagol'noi leksiki $v$ drevnerusskikh i starorusskikh tekstakh. V: Slovo v yazyke i tekste, 42-55. Volgograd: Volgogradskoe nauchnoe izdatel'stvo.

Dmitrieva, E.G., Akimova, E.N. (2011). Funktsii emotivnoi leksiki v Povesti o Petre i Fevronii. Vestnik Volgogradskogo gosudarstvennogo universiteta, Seriya 2, Yazykoznanie. № 2(14), $45-49$.

Georgievskii, V.T. (1914). Zhitie i podvigi svyatitelya Ilariona, mitropolita Suzdal'skago. Petrograd": Cvnodal'naya Tipografiya.

Igumen Damaskin (Orlovskii) (2002). Zhitie svyashchennomuchenika Amfilokhiya (Skvortsova), episkopa Krasnoyarskogo. Tver': «Bulat».

Rakhmanin", E. (1908a). Prot. Raba Bozhiya Anna (Yurodivaya Anna Ivanovna Lashkina ili Lukasheva). St. Petersburg": «Elektropechatnya» Ya. Krovitskogo.

Rakhmanin", E. (1908b). Prot. Raba Bozhiya Blazhennaya Kseniya. St. Petersburg": «Elektropechatnya» Ya. Krovitskogo.

Shakhovskii, V.I. (2009). Yazyk i emotsii v aspekte lingvokul'turologii. Volgograd: Peremena.

Slovar' tserkovno-slavyanskago i russkago yazyka, sostavlennyi Vtorym" otdroleniem" Imperatorskoi Akademii nauk": v 4 t. (1847a). T. 2. St. Petersburg": V" Tipografii Imperatorskoi Akademii nauk".

Slovar' tserkovno-slavyanskago i russkago yazyka, sostavlennyi Vtorym" otdroleniem" Imperatorskoi Akademii nauk": v 4 t. (1847b). T. 4. St. Petersburg": V" Tipografii Imperatorskoi Akademii nauk".

Svyataya blazhennaya Kseniya Peterburgskaya (2014). Moscow: Blagovest.

Trubetskoi, N.S. (1995). Istoriya. Kul'tura. Yazyk. Moscow: Izdatel'skaya gruppa «Progress».

Vilyunas, V.K. (1998). Osnovnye problemy psikhologicheskoi teorii emotsii. V: Psikhologiya emotsii. Teksty, 3-28. Moscow: Izdatel'stvo Moskovskogo universiteta.

Zhitie moldavskago startsa Paisiya Velichkovskago (perelozheno so slavyanskago na russkii yazyk" arkhim. A.) (1906). Svyato-Troitskaya Sergieva Lavra: Sobstvennaya tipografiya.

Zhitie prepodobnogo Antoniya (2017). V: Prepodobnye startsy Optinskie. Zhitiya i nastavleniya, 135-156. Vvedenskii stavropigial'nyi muzhskoi monastyr'. Optina pustyn'.

Zhitie prepodobnogo L'va, startsa Optinskogo (2017). V: Prepodobnye startsy Optinskie. Zhitiya i nastavleniya, 35-50. Vvedenskii stavropigial'nyi muzhskoi monastyr'. Optina pustyn'.

Zhitie prepodobnogo Varsonofiya (2017). V: Prepodobnye startsy Optinskie. Zhitiya i nastavleniya, 345-363. Vvedenskii stavropigial'nyi muzhskoi monastyr'. Optina pustyn'.

Zhitie svyatogo Pavla, startsa i chudotvortsa Taganrogskogo (2001). Moscow: Lestvitsa. 